https://doi.org/10.19195/0137-1150.173.33

Data przesłania artykułu: 22.09.2019

Data akceptacji artykułu: 17.01.2020

KAROLINA ZIEMKA

Uniwersytet Wrocławski, Polska

\title{
Pamięć jako forma terapii — autobiografizm w prozie Oty Pavla
}

Dyskurs pamięci cieszy się dużym zainteresowaniem wśród badaczy, zwłaszcza z powodu swojej wieloaspektowości. Na pytanie, czym jest pamięć w literaturze, odpowiedzi udziela Elżbieta Rybicka w artykule Miejsce, pamięć, literatura (w perspektywie geopoetyki):

Czym jest zatem pamięć w literaturze? Zarówno motywacją i budulcem architektoniki rzeczywistości przedstawionej (czyli konceptem literaturoznawczym), jak i kategorią egzystencjalną warunkującą tożsamość indywidualną oraz bycie w świecie (więc pojęciem ze słownika antropologicznego), a wreszcie medium przeszłości i nośnikiem pamięci zbiorowej (w perspektywie socjokulturowej) ${ }^{1}$.

Literackie retrospektywy są swoistym nośnikiem wspomnień, pozwalającym na rekonstrukcję minionej rzeczywistości — zarówno tej historycznej, jak i prywatnej. Przestrzeń problemowa związków, jakie zachodzić mogą między literaturą a pamięcią, jest rozbudowana, choć nie była nigdy rozumiana jako pełnoprawna kategoria literaturoznawcza, jej teorie mają charakter interdyscyplinarny.

Pamięć jako kategoria transdyscyplinarna okazała się zatem doskonałym pomostem pomiędzy dyskursem historycznym i literackim, zapewne głównie ze względu na indywidualny, prywatny charakter. Domeną literatury jest przecież pamięć jednostkowa, migawkowa, zawodna, a nie zobiektywizowana wizja historii ${ }^{2}$.

Motyw pamięci obecny jest w utworach Oty Pavla — jednego z najbardziej rozpoznawalnych czeskich prozaików. Mimo stosunkowo niewielkiego dorobku literackiego na dobre wpisał się zarówno w krajobraz literacki Czechosłowacji lat siedemdziesiątych, jak i tradycji europejskiej literatury żydowskiej, w szczególno-

${ }^{1}$ E. Rybicka, Miejsce, pamięć, literatura (w perspektywie geopoetyki), „Teksty Drugie” 2008, nr $1-2$, s. 23.

2 Ibidem, s. 22. 
ści autobiograficznymi opowiadaniami ze zbiorów Śmierć pięknych saren (Smrt krásných srnců, 1971) i Jak spotkatem się z rybami (Jak jsem potkal ryby, 1974).

Urodził się w Pradze w 1930 roku w rodzinie żydowskiego komiwojażera Leo Poppera. Wczesne dzieciństwo spędził w stolicy, później jego rodzina przeprowadziła się do Buštěhradu. Podczas drugiej wojny światowej jego ojciec i dwóch starszych braci Jiří i Hugo zostali wywiezieni do obozów koncentracyjnych, z których szczęśliwie po wojnie zostali uwolnieni. On, wraz z matką Herminą Czeszką, pozostał w domu. Kilkakrotnie wspomina o tym w swoich opowiadaniach: „Moi braciszkowie Hugo i Jurek byli jeszcze chłopcami, kiedy kazano im odłożyć wędki i włączyć się w pochód śmierci. Hugo zamiast wielkiej, srebrnej ryby, którą zamierzał złapać, ujrzał napis TEREZIN. Jurek zamiast wielkiego czarnego szczupaka: AUSCHWITZ"3. Dzieciństwo czy wczesna młodość braci zostały przedwcześnie, drastycznie przerwane. To właśnie między innymi traumatyczne doświadczenie wojny i holocaustu miało wpływ na kształtowanie się największych dzieł pisarza - wcześniej już wspomnianych zbiorów opowiadań. Po wojnie Pavel skończył studia i pracował jako komentator i dziennikarz sportowy. Jest autorem reportaży i opowiadań o tematyce sportowej. Miał problemy ze zdrowiem psychicznym, w 1964 roku zdiagnozowano u niego psychozę maniakalno-depresyjną z elementami schizofrenii.

Pod koniec życia największą ambicją Pavla było zostać pisarzem, co w końcu mu się udało, chociaż za życia nie zdążył doświadczyć wielkiej sławy. O tym, że pisanie tekstów o tematyce sportowej mu nie wystarcza, wspomniał w jednym z listów do brata z lat sześćdziesiątych. Wyznał, że chciałby opowiedzieć historie ze swojego życia:

Pisanie o sporcie jest wdzięczne, ponieważ wiele osób się tym zajmuje. Ale moim najskrytszym marzeniem jest - jeśli będę zdrowy — napisać o normalnym życiu. O starym Proszku. O Franku z „u Agenta”, o pustelniku ze Skryii, książkę opowiadań o naszym tacie i mamie itd. ${ }^{4}$

Sporą część życia spędził w szpitalach psychiatrycznych — był hospitalizowany szesnaście razy, gdy tylko jego stan się poprawiał, wyruszał za miasto do swoich ulubionych miejsc nad wodą. Ulgi szukał w kontakcie z naturą oraz łowieniu ryb nad swoją ukochaną rzeką Berounką. Wyraz tego dawał w swoich utworach: „Rzekę kochałem bardziej niż cokolwiek na świecie"5. Podczas choroby nie porzucił pisania, a wręcz przeciwnie - stworzył swoje najlepsze utwory. Pisanie opowiadań, w których przywoływał wspomnienia z dzieciństwa, opisywał swoich najbliższych i miejsca, które kojarzyły mu się ze szczęśliwymi chwilami, było swoistą terapią dla cierpiącego na ciężką chorobę psychiczną pisarza.

${ }^{3}$ O. Pavel, Śmierć pięknych saren, przeł. A. Czcibor-Piotrowski, J. Waczków, Warszawa 2011, s. 162.

4 O. Pavel, Z korespondence, Praha 1990, s. 71-72.

5 O. Pavel, Śmierć pięknych saren..., s. 120. 
W opowiadaniach tych autor wraca pamięcią do swojego dzieciństwa. Jako pół-Żyd dorastający w okresie drugiej wojny światowej doświadczył wiele cierpienia. Istotne $\mathrm{w}$ kwestii ich recepcji jest, w jaki sposób i kiedy powstały. Pavel przez połowę życia cierpiał na chorobę psychiczną. Jej pierwsze oznaki pojawiły się już u około dwudziestoletniego Oty podczas pełnienia służby wojskowej. W pełni choroba ujawniła się na zimowych igrzyskach olimpijskich w Innsbrucku, na której występował w roli komentatora sportowego.

W Epilogu do Jak spotkatem się z rybami wspomina to tak:

Dostałem pomieszania zmysłów na zimowej olimpiadzie w Innsbrucku. Mózg mi się zaćmił, jak gdyby spłynęła mgła z Alp. Zobaczyłem pewnego pana jako diabła w całej okazałości, miał rogi, kopyta, sierść i wiekowe spróchniałe zęby. Potem poszedłem w góry nad Innsbruckiem, żeby podpalić zabudowania wiejskie. Byłem przekonany, że taka jasność rozproszy mgłę 6 .

Z tego względu opowiadania, mimo że z całą pewnością mają charakter autobiograficzny, zawierają liczne elementy fabularyzowane.

Z punktu widzenia psychologii pamięć autobiograficzna odnosi się do osobistej przeszłości człowieka, wspomnień związanych z jego tożsamością, osadzona jest w doświadczeniu i emocjach ${ }^{7}$. Motyw pamięci autobiograficznej na gruncie literackim odnaleźć można $\mathrm{w}$ prozie Pavla, która ma retrospektywny charakter, choć pamięć pojawia się tu niejako pod dwiema postaciami. Pierwszą z nich jest ta odnosząca się do przeżyć osobistych, będąca emocjonalną reprodukcją przebytych traum. Drugą jest pamięć o utraconych miejscach i ludziach, pamięć małej ojczyzny, nostalgiczna tęsknota za znanymi przestrzeniami, ale nadal pozostająca w przestrzeni osobistej, bardzo subiektywnej mimo swych historycznych uwarunkowań i związków z wojennym krajobrazem.

Choć wieloaspektowy charakter autobiografizmu nie pozwala na jego jednoznaczne zdefiniowanie, to na gruncie literaturoznawczym filarem, na którym się opiera, jest tak zwany pakt autobiograficzny Philippe'a Lejeune'a. Według Lejeune'a ,warunkiem koniecznym dla zaistnienia tego rodzaju wypowiedzi jest tożsamość autora, narratora i głównego bohatera"8.

W przypadku prozy Pavla można mówić jedynie o elementach autobiografizmu, nie zaś pełnej zgodności opowieści literackiej z rzeczywistością. $\mathrm{W}$ jego utworach granica między autobiografizmem a fikcją jest płynna — prawdziwe wydarzenia mieszają się ze zmyśleniem, czasem nie do końca świadomą, spowodowaną chorobą umysłową, kreacją. Można natomiast rozwiać wątpliwości dotyczące tożsamości — autor sam jest narratorem, pisze o sobie, swojej rodzinie i bliskich, postaci, jak i wydarzenia historyczne, są autentyczne.

6 Ibidem, s. 196.

7 Por. A. Rybak-Korneluk et al., Pamięć autobiograficzna i jej znaczenie w wybranych zaburzeniach psychicznych, „Psychiatria Polska” 2016, nr 50.

8 Ph. Lejeune, Pakt autobiograficzny, przeł. A. W. Labuda, „Teksty: Teoria Literatury, Krytyka, Interpretacja” 1975, nr 5, s. 32. 
Zaciera różnice między prawdą a wyobraźnią. Jego pamięć autobiograficzna, czyli ta odnosząca się do własnej przeszłości, której nośnikiem są wspomnienia konkretnych postaci lub abstrakcyjnych informacji przekazywanych za pomocą języka, zaciera się i zlewa z wytworami wyobraźni — z jednej strony wpływać na to może choroba psychiczna, $\mathrm{z}$ drugiej traumy przeżyte $\mathrm{w}$ dzieciństwie. Podstawową tezą podejścia psychoanalitycznego jest twierdzenie, że przeżyte $\mathrm{w}$ dzieciństwie bolesne doświadczenia i thumione cierpienie mają istotny wpływ na kształtowanie się osobowości. Według Zygmunta Freuda, który pojęcia traumy używał metaforycznie, w znaczeniu rany czy uszkodzonej tarczy ochronnej umysłu, psychika człowieka może zostać „zraniona” przez różnego rodzaju przykre przeżycia ${ }^{9}$. Takich przeżyć doświadczył Pavel wiele.

Opowiadania ze zbioru Śmierć pięknych saren (w Polsce pod tym tytułem wydane zostały dwa zbiory: Śmierć pięknych saren oraz Jak spotkatem się z rybami) zaczęły powstawać w 1967 roku. W tym czasie stan psychiczny Pavla znacznie się pogorszył - był bardzo niestabilny, miał silne skłonności do stanów depresyjnych. To właśnie pisanie stało się dla niego odskocznią od ciężkiej choroby - cały swój czas poświęcał na pisanie, całą swoją uwagę skupiał na pisaniu. Opowiadania z tego zbioru odnoszą się do licznych elementów z biografii autora. Opisuje w nich wydarzenia z życia swojej rodziny, a przede wszystkim ojca — Leo Poppera, który staje się swoistym superbohaterem — wyidealizowaną osobą o nadprzyrodzonych zdolnościach. Pisarz stworzył mityczny obraz ojca, któremu nawet komiczne niepowodzenia nie ujmują wspaniałości. Niektóre z opisywanych zdarzeń są bardzo przerysowane, zdają się nierealne. Jak choćby ogromny handlowy sukces podczas pracy dla szwedzkiej firmy:

Jeśli idzie o liczbę sprzedanych odkurzaczy i lodówek, pobił swoimi wynikami rekordy komiwojażerów z pięćdziesięciu pięciu krajów świata, a w samej tylko Japonii Elektrolux miał dwa tysiące przedstawicieli i wszyscy walczyli o ten zaszczytny tytuł. Zdobył go tatuś, wyprzedzając pewnego kolegę z Buenos Aires. Sprzedał najwięcej odkurzaczy na świecie i udawały mu się rzeczy wprost niewiarygodne. Sprzedał odkurzacze chłopom w Nesuchyni, gdzie dotychczas nie mieli prądu elektrycznego ${ }^{10}$.

Bohaterami jego opowiadań są realne postacie. Oprócz ojca pojawia się również matka Hermiona, bracia Jiři i Hugo czy przyszywany wujek Proszek. W tym zbiorze wydarzenia są ułożone chronologicznie - najpierw czas przed drugą wojną światową, czyli dzieciństwo Pavla, następnie okres wojny — dorastanie w trudnych warunkach i wydarzenia powojenne — próba powrotu do normalnego życia po traumatycznych przejściach.

Autor zaciera różnicę między pamięcią a wyobraźnią. Tym zabiegiem być może próbował poradzić sobie z bardzo przecież przykrymi wydarzeniami z dzieciństwa. Jego pamięć jest wybiórcza — okrutne czasy wojny zdają się w opowiadaniach jedynie mało istotnym tłem sielanki dzieciństwa. Pavel, opisując w opowia-

9 Por. Z. Freud, Poza zasada przyjemności, przeł. J. Prokopiuk, Warszawa 2005.

10 O. Pavel, Śmierć pięknych saren..., s. 20. 
daniach tragiczne wydarzenia, zestawia je z sielankowym dzieciństwem. Pamięć zniekształca traumatyczne przeżycia, przedstawia je w zupełnie innym świetle — jako pełen ciepła okres wieku dziecięcego — idealizuje wspomnienia, aby poradzić sobie z przeżytą traumą.

Czas wojny nie był łatwy, szczególnie dla żydowskiej rodziny. Codzienne funkcjonowanie wiązało się ze strachem i cierpieniem zarówno psychicznym, jak i fizycznym. Wspomnienia tego typu z pewnością nie utworzą obrazu sielankowego dzieciństwa. W prozie Pavla jednak traumatyczne przeżycia czasu wojny stają się jakby tłem przyjemnych epizodów z życia rodziny. Na pierwszy plan wysuwają się sceny ukazujące miłe chwile spędzane na łonie natury, relaksujące łowienie ryb czy spektakularne sukcesy ojca. Jak na przykład w opowiadaniu Karpie dla Wermachtu, w którym Leo Popper, ryzykując życiem, aby wykarmić rodzinę, wykradł karpie ze skonfiskowanego przez nazistów stawu: „A ja wówczas pomyślałem sobie, że ta orkiestra gra właściwie tylko i wyłącznie na cześć mojego taty, który z gwiazdą Dawida na płaszczu sprzątnął Niemcom sprzed nosa ryby ze stawu" ${ }^{\prime 1}$. To właśnie stosunek Pavla do ojca zasługuje na szczególną uwagę. Jego postać jest wyidealizowana, jego nie do końca uczciwe poczynania, które nie miały na celu dobra rodziny (jak na przykład romanse), przedstawiane są jako niewinne wybryki. W opowiadaniach przejawia się to komizmem o lekko gorzkim zabarwieniu. Ojciec — emocjonalnie rozchwiany wzór męskości — to z jednej strony bohater stawiający czoła niebezpieczeństwu w imię dobra rodziny, z drugiej zabawny nieudacznik, niepoprawny romantyk, nieodpowiedzialny, porywczy pracoholik, który wykazywał tendencję do maniakalnych zachowań. To również naiwny idealista, który marzył o stawie pełnym ryb, dał się zmanipulować i kupił taki, w którym pływał jeden, za to bardzo okazały i jak mówi tytuł opowiadania — Najdroższy w Europie Środkowej karp.

W opozycji do osoby ojca jawi się w opowiadaniach postać Karola Proszka gruboskórnego, oschłego przyszywanego wujka, który w chłopcu budził skrajnie różne uczucia. $Z$ jednej strony mały Ota go podziwiał, niemal wielbił ze względu na jego przymioty męskości (męskie zajęcia itp.), ale z drugiej czuł się odpychany, odnosił wrażenie, że wuj nie darzy go sympatią, bo nie spełnia jego oczekiwań. „Poczłapałem do niego bez pośpiechu, nie lubił mnie zbytnio. Przepadał głównie za Jurkiem, to był lump w jego typie"12.

Obu opisuje już dorosły człowiek, poświęcając im ogrom uwagi na kartach opowiadań — to właśnie ci dwaj, tak od siebie różni mężczyźni, mieli wpływ na kształtowanie się osobowości Pavla. Poza mocnym związkiem emocjonalnym z Otą obaj mają jeszcze jedną wspólną cechę — przedstawieni są jako wspaniali mężczyźni, którzy byli wzorem dla małego chłopca, mają niemalże nadprzyrodzone zdolności, są obiektem zachwytu chłopca, a później już dorosłego pisarza.

11 Ibidem, s. 57.

12 Ibidem, s. 90. 
W opowiadaniach ze zbioru Śmierć pięknych saren Pavel powraca pamięcią do miejsc, w których jako dziecko spędzał rodzinne wakacje. Ujawnia się tu intensywny stosunek emocjonalny do krajobrazu, z którym wiążą się ciepłe wspomnienia, beztroska i szczęście odczuwane tam w latach wczesnej młodości. Znamienne jest, że podczas ciężkiej choroby psychicznej ulgę przynoszą Pavlovi obrazki znad Berounki. W chwilach gdy jego stan się poprawiał, wracał tam, zażywał spokoju, kontakt z przyrodą był leczniczy, w całości poświęcał się łowieniu ryb. Gdy jego zdrowie nie pozwalało na podróż nad rzekę, próbował wracać do niej pamięcią, pisząc opowiadania i jednocześnie spełniając swoje największe marzenie o tym, aby zostać pisarzem.

Idylliczne wspomnienia z wakacji spędzonych nad rzeką zmieniają się w retrospekcje tragicznych wydarzeń okresu wojny. Jednak nawet to Pavel opisuje w charakterystyczny dla swoich opowiadan sposób: brakuje tu jakiegokolwiek patosu, negatywnego zabarwienia emocjonalnego, przedstawia to beznamiętnie, zwięzłymi zdaniami, jakby dopowiadał mało istotny element historii.

W tytułowym opowiadaniu przywołuje udane polowanie (w zasadzie kłusownictwo), opowiada o radości, która wynikła z dostatku — było co i czym świętować. Pisarz opisuje znajome mu potrawy, ma w pamięci ich smaki i zapachy. Tego typu przyjemne wspomnienia kończy, jak gdyby mimochodem dorzucając krótkie, ironiczne zdanie o rozpoczęciu wojny:

Od nowego dnia, jeśli idzie o te sprawy, zapanował tam istny raj. Gramofon Odeon wygrywał „Tysiąc mil” i przyrządzało się sarninę w śmietanie z knedlami i wszystkie te miejscowe branowskie potrawy jak ziemniaki i knedle, zwane „węglarz”, albo knedle z masłem czy placki kartoflane zapiekane w piekarniku, zwane „bac”. Jezu Chryste, to ci były specjały! I nagle wszystko się skończyło, bo przyszedł były kapral Adolf Hitler, który miał pod nosem wąsik jak mój ukochany wuj Karol Proszek ${ }^{13}$.

Pavel lakonicznie przedstawia tragiczne wydarzenia wojny, których nie potrafi całkowicie wyprzeć z pamięci. Osią jego opowiadań są rodzinne, sielankowe wspomnienia. Pisarz, aby poradzić sobie z przeżytą traumą, manipuluje pamięcią, koloryzuje wspomnienia, dodaje do nich coś ze swojej wyobraźni, jakby odczarowywał bolesne wspomnienia, zmieniając zupełnie ich status. W opowiadaniu Ostateczne rozwiazanie kwestii robactwa już sam tytuł nawiązuje do holocaustu. W jego treści natomiast uwagę zwraca to, w jak lekki, niemal zabawny sposób autor przywołuje tragiczne epizody z życia swojej rodziny, takie jak śmierć babci w obozie koncentracyjnym: „Po wojnie brakowało dobrego towaru »sam szmelc, szajs, czyli gówno« - jak powiedziałaby nasza babcia Popperowa z Busztegradu, którą Niemcy zagazowali w Auschwitz"14. W tym krótkim zdaniu przywołane zostały dwie, zupełnie nieprzystające do siebie rzeczy, o całkowicie odmiennym ładunku emocjonalnym - zabawne powiedzenie babci i informacja o tym, że została ofiarą holocaustu.

\footnotetext{
13 Ibidem, s. 40.

14 Ibidem, s. 63.
} 
Więcej o okrucieństwie wojny Pavel pisze w opowiadaniu Karpie dla Wermachtu. Opowiada w nim historie o tym, jak ojciec wykrada karpie ze skonfiskowanego przez nazistów stawu. Jako naoczny świadek opisuje tragiczne wydarzenie, jakim było zrównanie z ziemią Lidic, wydarzenie, które dogłębnie go dotknęło, bo nie było tylko kartą $\mathrm{z}$ historii.

Okupacja wszędzie była zła, ale w Busztegradzie jeszcze odrobinę gorsza. Zagłada Lidic wstrząsnęła całym światem. Ale Busztegrad, mój tatuś, mamusia, bracia, ja, my wszyscy widzieliśmy, jak Lidice płonęły, my słyszeliśmy, jak Lidice krzyczały zza wzgórza ${ }^{15}$.

W opowiadaniu tym również mowa o trudnych dla rodziny chwilach. Pavel nie zmienia stylu wypowiedzi, wplata krótkie, pisane potocznym językiem zdania - jakby sprawozdanie z czegoś, co się już stało, czego nie dało się uniknąć: „A potem spadł na nas straszliwy cios. Moi bracia musieli pójść do obozu koncentracyjnego"16 oraz „Tuż przed Bożym Narodzeniem tatusia powołano do obozu koncentracyjnego. Powodziło się nam wówczas już dość kiepsko, mamusia skarżyła się, że nic nie będzie mu mogła dać na drogę"17. Zdanie to wywołuje wrażenie, jakby ojciec był pracownikiem, który wyjeżdżał w obowiązkową długą podróż służbową, a nie Żydem wywożonym do obozu zagłady.

Zbiór Jak spotkatem się z rybami zawiera historie o łowieniu ryb. Historie bardziej liryczne od poprzednich, w których opisy przyrody są znacznie bardziej rozbudowane i w których widać intensywniejsze zabarwienie emocjonalne. Osią ich już nie jest postać ojca, ale sam narrator — Ota Pavel i jego przeżycia, którym poświęca zdecydowanie więcej uwagi.

Stosunek Pavla do opisywanych obszarów jest bardzo emocjonalny. Opowiadania pełne są wspomnień znajomych mu krajobrazów znad Berounki. Te historyjki o wędkarskich wyprawach opowiadane są z perspektywy tego samego chłopca, który w wyprawach uczestniczył, które wywarły wpływ na jego osobowość, które stworzyły bardzo intensywne, fascynujące wspomnienia, które przywoływane w dorosłym życiu pozwalają choć na chwilę uciec od choroby.

Zbiór otwiera część pod tytułem Dzieciństwo. Wyróżnia się tu postać przewoźnika Proszka. To dzięki niemu mały Ota zapałał miłością do natury i to przy jego boku stawiał swoje pierwsze wędkarskie kroki. Okres dzieciństwa kojarzył się mu z beztroskim czasem spędzanym nad rzeką wraz z rodzicami, braćmi i przyszywanym wujkiem.

W opowiadaniu Moja pierwsza ryba autor wspomina swoją pierwszą wędkarską przygodę, gdy zaczęła się jego fascynacja łowieniem. Była to swoista inicjacja, która dziecko zbliżyła do męskiego świata. Z pewnością jest to jedne $\mathrm{z}$ istotniejszych wydarzeń dzieciństwa Pavla — pewna cezura, która w jego pamięci otworzyła drogę ku dorosłości, jako najmłodszy z rodzeństwa chciał się wkupić w łaski starszych braci. Wspomnienie o tym jest przerysowane: „To nie była ryba,

\footnotetext{
15 Ibidem, s. 52.

16 Ibidem.

17 Ibidem, s. 53.
} 
to był smok, opancerzony rycerz z purpurowym pióropuszem na przyłbicy" 18 . Dla autora rzeka pełna ryb jest symbolem szczęśliwego dzieciństwa - wszystkie najprzyjemniejsze i najbardziej intensywne przeżycia z wczesnej (i nie tylko) młodości związane są właśnie z nią.

Jak w zbiorze Śmierć pięknych saren, tak i tutaj pojawia się motyw wojny, której nie da się wyrzucić z pamięci. Jej okrucieństwo przedstawione jest krótkimi, niemalże zdawkowymi wypowiedziami z perspektywy dziecka, bez gniewu: „Od tego dnia przeszło kawał czasu. Co też porabia Hugo? Pewnie zamiast chleba wozi na wózku umarłych na spalenie" 19 . Autor wielokrotnie na kartach opowiadań odnosi się bezpośrednio do wydarzeń ze swojego życia, co chwilami sprawia wrażenie zapisków z pamiętnika, jednak dość chaotycznego, pisanego chronologicznie, jednak z pominięciem szczegółowych dat. „Najpiękniej na świecie podróżuje się kanadyjką. Pięć razy wypuszczałem się Lużnicą i Wełtawą, wszystkiego pięć razy przed swoją chorobą"20.

W Epilogu Pavel porównuje życie do rzeki, co obrazuje, jak ważną rolę odgrywał czas spędzony na łonie natury nad Berounką czy stawami i potokami. Mimo wielu bliższych i dalszych podróży, które odbył jako dziennikarz sportowy, najpiękniejszym wspomnieniem był właśnie czas spędzony nad wodą w kraju dzieciństwa. Zawsze wracał nad ich brzeg, jeśli pozwalało na to zdrowie - fizycznie, a jeśli nie, to chociaż pamięcią, co najlepiej obrazuje cytat:

Kiedy czułem się lepiej, myślałem o tym, co było w życiu najpiękniejsze. Nie myślałem o miłości ani o tym, że się włóczyłem po świecie. Nie myślałem o nocnych lotach przez oceany ani o tym, jak grałem w praskiej Sparcie w kanadyjskiego hokeja.

Chodziłem znowu na ryby — nad potoki, rzeki, stawy i przegrody. I uzmysłowiłem sobie, że najpiękniejsze, co na świecie przeżyłem, to było właśnie to ${ }^{21}$.

Proza Pavla z pewnością zawiera liczne elementy autobiograficzne. Oczywiste jest też, że nie można wszystkich wydarzeń i postaci literacki przenosić jeden do jednego z kart opowiadań do rzeczywistości. Jest to fikcja z wieloma odniesieniami do świata rzeczywistego. Jednak w opowiadaniach wspomnienia mieszają się z wytworami wyobraźni. Trudno określić jednoznacznie, czy to upiększanie, koloryzowanie rzeczywistości to celowy zabieg autora, czy może jedynie zaburzenia związane z chorobą psychiczną, która sprawiała, że pamięć zawodziła, a to, co zmyślone, mieszało się z prawdą. Należy stwierdzić, że pamięć odegrała znaczącą rolę w jego twórczości. $Z$ jednej strony pamięć autobiograficzna — wspomnienia szczęśliwego dzieciństwa i traum, którymi dotknięta została rodzina, z drugiej natomiast zatarta granica między pamięcią a imaginacją, fabularyzowane wspomnienia, manipulowanie pamięcią i traktowanie jej jak terapii. Terapii pomagającej w przetwarzaniu traumatycznych przeżyć w miłe, kojące wspomnienia jak z bajki,

\footnotetext{
18 Ibidem, s. 92.

19 Ibidem, s. 111.

20 Ibidem, s. 125.

${ }^{21}$ Ibidem, s. 197.
} 
w których te złe wydarzenia są czymś, z czym trzeba i można się pogodzić. W tej autobiograficznej prozie można znaleźć zarówno świadomy zapis wątków autobiograficznych, odniesienia do egzystencjalnych problemów pokolenia dotkniętego traumą holocaustu, jak i częściowo zmyślone historyjki z bohaterami inspirowanymi realnymi osobami.

Celowo mieszamy tu określenia typu postać, osoba, bohater — bo każda z nich jest jednocześnie trochę realna i trochę zmyślona. Trudno określić, gdzie przebiega granica między prawdą a wytworem wyobraźni. Najprawdopodobniej sam autor nie wiedział, co jest prawdziwym, a co już przekształconym przez wyobraźnię wspomnieniem.

\section{Bibliografia}

Czermińska M., Trójkąt autobiograficzny. Świadectwo, wyznanie i wyzwanie, Universitas, Kraków 2000.

Freud Z., Poza zasada przyjemności, przeł. J. Prokopiuk, Wydawnictwo Naukowe PWN, Warszawa 2005.

Kaczorowski A., Ota Pavel. Pod powierzchnia, Wydawnictwo Czarne, Wołowiec 2018.

Lejeune P., Pakt autobiograficzny, przeł. A. W. Labuda, „Teksty: Teoria Literatury, Krytyka, Interpretacja” 1975, nr 5.

Lubas-Bartoszyńska R., Między autobiografia a literatura, Państwowe Wydawnictwo Naukowe, Warszawa 1993.

Pavel O., Śmierć pięknych saren, przeł. A. Czcibor-Piotrowski, J. Waczków, Agora, Warszawa 2011. Pavel O., Z korespondence, Primus, Praha 1990.

Růžičková M., Ota Pavel — osobnost dvou tvář́, Petrklíč, Praha 2008.

Rybak-Korneluk A., Wichowicz H., Żuk K., Dziurkowski M., Pamięć autobiograficzna i jej znaczenie w wybranych zaburzeniach psychicznych, „Psychiatria Polska” 2016, nr 50.

Rybicka E., Miejsce, pamięć, literatura (w perspektywie geopoetyki), „Teksty Drugie” 2008, nr 1-2.

\section{Memory as a Form of Therapy - Autobiographism in Ota Pavel's Prose}

\section{Summary}

Ota Pavel was one of the most famous Czech prose writers. His literary works contain many references to his biography. Pavel was mentally ill, writing down memories was a form of therapy. Autobiographism, which is intertwined with fictionalized narratives, became one of the main elements of his work.

Keywords: Ota Pavel, prose, memory, autobiographism 


\section{Pamět' jako forma terapie - autobiografismus v próze Oty Pavla}

Shrnutí

Ota Pavel byl jedním z nejznámějších českých prozaiků. Je autorem autobiografických próz $\mathrm{s}$ tématy $\mathrm{z}$ vlastního života. Pavel trpěl duševní chorobou, jednou z forem jeho terapie było zapisování vzpomínek. Autobiografismus se stal jedním z hlavních prvků jeho práce, ve které se prolínal $\mathrm{s}$ beletrizovanými př́iběhy.

Klíčová slova: Ota Pavel, próza, pamět', autobiografismus 